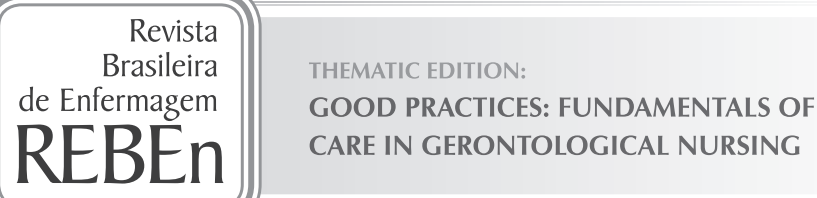

\title{
Social representations of older adults regarding quality of life
}

\author{
Representações sociais de idosos sobre qualidade de vida \\ Representaciones sociales de ancianos sobre calidad de vida
}

\begin{abstract}
Marielle Cristina Gonçalves Ferreira', Luiz Fernando Rangel Tura', Rafael Celestino da Silva', Márcia de Assunção Ferreira'
\end{abstract}

'Universidade Federal de Rio de Janeiro, Nursing School Anna Nery, Postgraduate Program in Nursing. Rio de Janeiro, Brazil.

How to cite this article:

Ferreira MCG, Tura LFR, Silva RC, Ferreira MA. Social representations of older adults regarding quality of life. Rev Bras Enferm [Internet]. 2017;70(4):806-13. [Thematic Edition "Good Practices: Fundamentals of care in Gerontological Nursing"] DOI: http://dx.doi.org/10.1590/0034-7167-2017-0097

Submission: 02-14-2017 Approval: 04-02-2017

\section{ABSTRACT}

Objective: to identify the social representations of older adults regarding quality of life, and to analyze the care practices adopted to promote it. Method: qualitative, exploratory, descriptive research, applying the Theory of Social Representations. Thirty older people from a Health Academy of Rio de Janeiro participated in the study. The software Alceste was used, and lexical analysis of data was performed. Results: social representations of quality of life are based on the social determinants of health; they evidence knowledge and practices of care by valuing physical activities. The practices promoting quality of life comprise healthy eating habits, daily physical exercise, social participation, interaction and socialization, accomplishment of leisure activities and daily tasks with independence and autonomy, and support and family contact. Final considerations: the elderly have a global understanding of the concept of quality of life, coordinate knowledge built in daily life and knowledge coming from the technical-professional field, which evidences the multidimensionality of the concept.

Descriptors: Quality of Life; Aged; Motor Activity; Health Promotion; Nursing.

\section{RESUMO}

Objetivo: identificar as representações sociais de idosos sobre qualidade de vida e analisar as práticas de cuidado por eles adotadas para promovê-la. Método: pesquisa qualitativa, exploratória, descritiva, com aplicação da Teoria das Representações Sociais. Participaram 30 idosos de uma Academia Carioca de Saúde. Utilizou-se o software Alceste e realizou-se análise lexical dos dados. Resultados: As representações sociais de qualidade de vida sustentam-se nos determinantes sociais de saúde, evidenciam saberes e práticas de cuidado, com valorização de atividades físicas. As práticas promotoras de qualidade de vida congregam hábitos alimentares saudáveis, exercícios físicos diários, participação social, convívio e interação, realização de atividades de lazer e tarefas cotidianas com independência e autonomia, apoio e contato familiar. Considerações finais: Os idosos têm uma compreensão global do conceito de qualidade de vida, articulam saberes construídos no cotidiano e advindos do campo técnico-profissional, o que evidencia a multidimensionalidade do conceito.

Descritores: Qualidade de Vida; Idoso; Atividade Motora; Promoção da Saúde; Enfermagem.

\section{RESUMEN}

Objetivo: identificar las representaciones sociales de ancianos sobre calidad de vida y analizar las prácticas de cuidado por ellos adoptadas para promoverlas. Método: investigación cualitativa, exploratoria, descriptiva, con aplicación de Teoría de las Representaciones Sociales. Participaron 30 ancianos de una Academia Carioca de Salud. Se utilizó software Alceste y se efectuó análisis lexical de datos. Resultados: las representaciones sociales de calidad de vida se sustentan en los determinantes sociales de salud, evidencian saberes y prácticas de cuidado, valorizando la actividad física. Las prácticas promotoras de calidad de vida incluyen hábitos alimentarios saludables, ejercitación física diaria, participación social, convivencia e interacción, realización de actividades recreativas y tareas cotidianas con independencia y autonomía; apoyo y contacto familiar. Consideraciones finales: los ancianos poseen una compresión global del concepto de calidad de vida, articulan saberes construidos en el día a día, devenidos del área técnico-profesional, evidenciando la multidimensionalidad del concepto.

Descriptores: Calidad de Vida; Anciano; Actividad Motora; Promoción de la Salud; Enfermería. 


\section{INTRODUCTION}

The increase in life expectancy and the aging of the population in Brazil and in the world have occurred in an accelerated fashion, which makes it important to reflect on the conditions under which the elderly are aging. Aging is a complex, intersectoral process that encompasses discussions on health, education, social assistance, social security, and housing, including the social and economic aspects that affect the quality of life of the aging population. In order that this intersectorality is put into practice, there must be some communication among public policies, and these should aim at the same interests: social protection and coping with social inequalities ${ }^{(1)}$.

Brazil has been trying to prepare itself to respond to the growing demands of its aging population, through actions and policies implemented with the purpose of guaranteeing the elderly rights to health and quality of life in the aging process. At present, the predominance of chronic non-degenerative diseases is highlighted, and they are a major cause of death, representing a great health problem ${ }^{(2)}$. In this context, promoting aging with quality of life becomes a challenge that requires strategies capable of modifying behavior towards healthy aging.

In the city of Rio de Janeiro, a program of activities called Academia Carioca da Saúde (Health Academy of Rio de Janeiro) has been conducted since 2009 with the objective of promoting health and preventing diseases and their complications, ensuring access for the population to practices promoting physical, mental, and social well-being. This program has proved to be a significant resource for the construction of a more active society with a healthier lifestyle and a better quality of life.

The phenomenon of quality of life in the health area has been conceptualized in two different ways: quality of life in a generic sense and in relation to health. The first presents a wider meaning, used in sociological studies, which are concerned with the cultural and social mobilization that this phenomenon imposes on society, and does not refer to it only as a process of illness or injury ${ }^{(3)}$. Regarding the different approaches, concepts, and evaluations, the scientific literature presents the discussion of several authors about this phenomenon ${ }^{(4)}$.

Quality of life is approached through discussions of representations, according to a polysemic notion, which includes different senses, meanings, knowledge, and experience. Considering this theoretical reference, the relation of the context in which people are inserted to their standard of behavior is worth mentioning.

Thus, the understanding of the construction of the knowledge of the elderly included in the program Academia Carioca on living with quality, and the links of this construction with the practices adopted for the benefit of health, constitute an instrument capable of subsidizing interventions that promote active and successful aging, meeting the problem outlined.

\section{OBJECTIVE}

To identify the social representations of older adults regarding quality of life, and to analyze the practices of care adopted to promote it.

\section{METHOD}

\section{Ethical aspects}

The study was approved by the Research Ethics Committee of the Nursing School Anna Nery/Health Care Institute São Francisco de Assis. The participants signed the Free and Informed Consent Term and had their identities kept confidential by using identification codes: male $(M)$ or female $(F)$, followed by the interview number and age.

\section{Theoretical-methodological framework}

The procedural approach of the Theory of Social Representations (TRS) was applied to explore the content that delineates the knowledge of the elderly about the object in question. Social representation is responsible for guiding behaviors and reshaping the elements of the environment in which they occur $^{(5)}$. Therefore, the application of the TRS in the present study aims to identify how the representation of quality of life affects the attitudes of the elderly, and in what way they can influence this in the context of the group of Academia Carioca.

\section{Study type}

This was a qualitative, exploratory, and descriptive study, with the goal of understanding the meanings attributed by the people to the researched object in its production context.

\section{Methodological procedures}

\section{Field}

Research was conducted from December 2015 to June 2016, in an Academia Carioca de Saúde at the Family Health Strategy Clinic located in the city of Rio de Janeiro. It is a space for health promotion, development of community, and multisectoral action, centered on the practice of physical activities. It has the participation of healthcare and physical education professionals who work as partners. This choice was made because it is a place of socialization among the elderly, where they establish conversations and acquire knowledge about health issues; therefore it is useful for the construction of social representations.

\section{Data source}

The source was a qualitative, non-probabilistic, random, and convenience sample. Inclusion criteria were: people aged 60 years and over; of both genders; with verbal communication and cognition preserved, who were participants for at least 30 days. Exclusion criteria were: irregular frequency of activities and/or absence on days of data collection. Participants were 30 elderly people, 25 women and five men, defined based on a preliminary analysis of the data and configuration of the empirical framework of the research. The sufficiency to answer the guiding questions and to reach the objectives determined the cessation of participant gathering ${ }^{(6)}$.

\section{Data collection and organization}

First, an exploratory observation and familiarization with the environment for later gathering of participants was performed for two months. In the second phase, an instrument was applied 
individually to collect the social and demographic data of the elderly. In the third phase, in-depth interviews (average duration of 60 minutes) were conducted with open questions about the daily life and activities performed by the participants in the spaces of the Academia de Saúde, maintaining the participants' privacy. The testimonies were transcribed using Alceste 2012 software standards.

\section{Data analysis}

Data analysis occurred after the interview processing in the Alceste software, which divided the text into elementary context units (uces), reducing the roots of the main words, and distributing the lexicons, separating them into frequencies and associations according to content similarity or non-similarity. The software captures groupings and performs lexical classifications, and the researcher is responsible for tracing the meanings of the formed classes, naming them and performing an analysis of the content based on the distribution and association of the lexicons. The class to be analyzed deals with the multidimensionality of the concept of quality of life, which emerged in lexical Class 1. Triangulation occurred in order to contemplate the analysis of the descending hierarchical classification, ascending hierarchical classification, and content of the units of the lexical class. This triangulation of data analysis applied in the studies of social representations is primordial for the deepening and validity of the results ${ }^{(7)}$.

\section{RESULTS}

Of the 30 participants in the study, 25 were female $(83.3 \%)$ and five were male (16.7\%). The age ranged from 60 to 82 years, according to the inclusion criterion in the sample, with a predominance of individuals between 60 and 65 years old (53.3\%). About 16 elderly people (53.3\%) were married, 20\% were divorced, $20 \%$ widowed, and $2 \%$ single. Most of them (90\%) lived with relatives, and only three (10\%) lived alone. Of the total number of participants, 18 (60\%) were retired and $12(40 \%)$ were still working.

As for the data processed by the Alceste software, the corpus submitted to the software analysis consisted of 30 units of the initial context (uci), which were distributed into 1,391 units of elementary context (uce), formed by 4,447 words or distinct words. The software reduced the vocabulary to its roots, originating 859 analyzable words (nouns, adjectives, verbs) and 266 supplementary forms (articles, pronouns). The processing resulted in the construction of five classes, which addressed: quality of life; daily life and leisure; and therapy applied in primary care and its consequences for health. To meet the objective of this article, we will specifically analyze Class 1 on the quality of life.

The multidimensionality of the concept of quality of life emerged in lexical Class 1 of the production of data processed by the Alceste software. This class consists of 436 uces, the equivalent of $46 \%$ of the uces used, and about 146 words analyzed, as shown in Figure 1.

In the descending hierarchical classification, most of the incidental terms refer to the psychosocial, subjective, and multidimensional aspects of the researched object (quality of life). Class 1 originated from the questions related to what the elderly think about their quality of life, through which means they construct their conceptions, knowledge, and how they act in relation to these factors; that is, it refers to the image they construct around the subject in question.

\begin{tabular}{|lrr|}
\multicolumn{3}{|c}{ Clas s e 1} \\
\hline Forme & Phi & Eff. \\
\hline qualidade_ & 0,40 & 172 \\
pesso & 0,28 & 226 \\
ach & 0,24 & 153 \\
viv & 0,24 & 89 \\
gente & 0,24 & 240 \\
aliment & 0,22 & 58 \\
dinheir & 0,19 & 80 \\
vida & 0,19 & 97 \\
procur & 0,17 & 62 \\
feliz & 0,16 & 33 \\
busc & 0,15 & 45 \\
com & 0,15 & 53 \\
form & 0,14 & 25 \\
atividade_ & 0,14 & 29 \\
condic & 0,13 & 25 \\
boa & 0,13 & 53 \\
consider & 0,13 & 18 \\
fundamen & 0,12 & 15 \\
tiv & 0,12 & 27 \\
tent & 0,12 & 22 \\
conviv & 0,12 & 23 \\
dev & 0,11 & 16 \\
uma & 0,12 & 256 \\
das & 0,11 & 37 \\
cois & 0,11 & 152 \\
pens & 0,11 & 37 \\
saud & 0,11 & 84 \\
\hline \hline Variable & Phi & Eff. \\
\hline *suj_25 & 0,26 & 93 \\
*esc_6 & 0,22 & 112 \\
*par_5 & 0,19 & 123 \\
*id_1 & 0,17 & 306 \\
\hline
\end{tabular}

Source: Alceste report, 2016.

Figure 1 - Descending hierarchical classification of Class 1

In the lexical analysis ascending hierarchical classification (AHC), shown in Figure 2, two groups stand out. The first bring together the words "money" and "want," which refer to the terms "conditions" and "I had," and both are connected to the words "I consider" and "happy." This, in turn, is linked to the second group of the terms "physical activity" and "should," which establishes relations with the words "food", "to eat", "good," and "health." These relationships express the social determinants of health and suggest the correlation with money and its importance for supportive care such as food.

Meanings highlighted were those that relate quality of life to social determinants and in what way they affect health. The uces in this class involve economic, cultural, and social situations related to housing, food, education, income, and employment conditions, which are states that influence health. The social determinants of health are present in many points in this class, especially in terms of aspects that involve financial and social difficulties, which permeate the representations and allow the emergence of existing inequalities and inequities in the population studied.

The associated lexicons and their meanings in the uces demonstrate a protagonism and a proactive movement of the elderly towards actions that take them to quality of life in the face of what they consider to be its promoter. This understanding can be identified in the verbs used in the construction of the thought expressed in the uces, such as "demand", "to do," and "to search." 


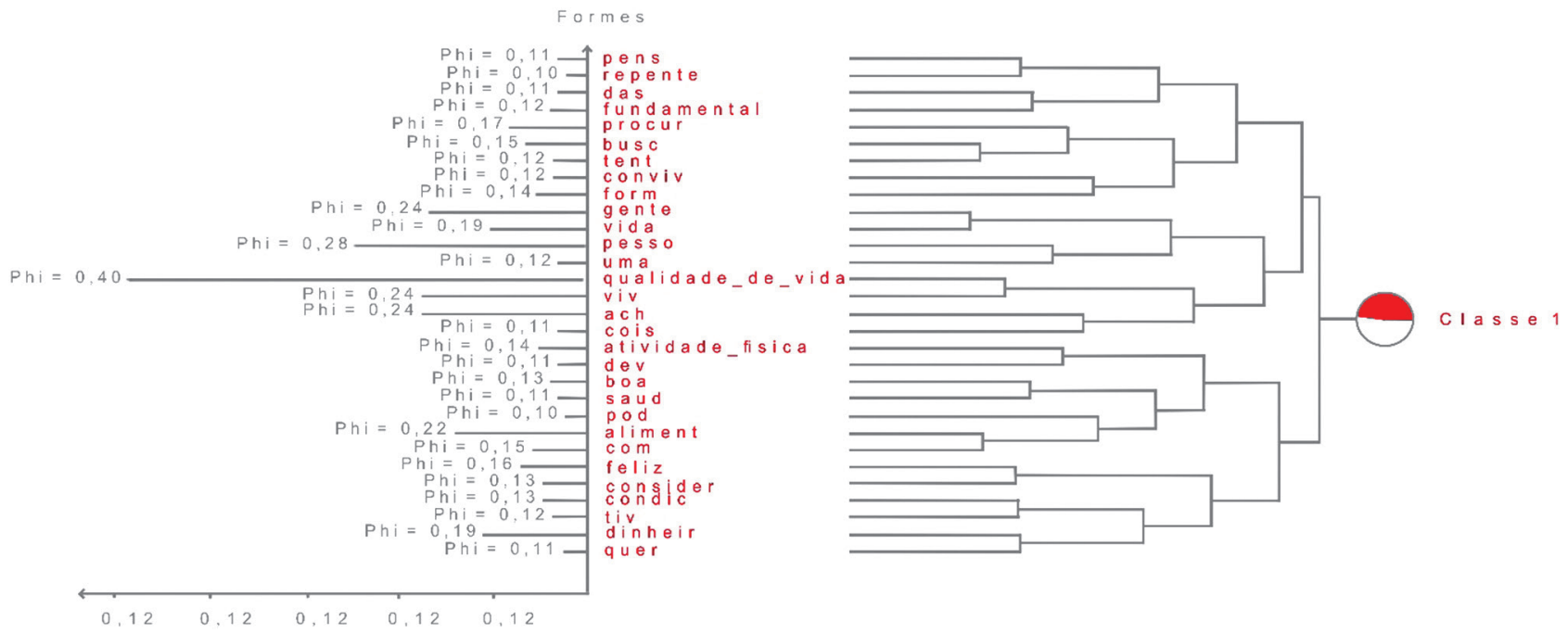

Source: Alceste report, 2016.

Figure 2 - Ascending hierarchical classification of Class 1

In the ascending lexical analysis it is observed that the lexicons "to try" and "to search" link to the verb "to look for," which expresses the proximity and frequency with which they are used together. They are linked to the lexicons "socialize with" and "way," which may mean that the elderly seek to live together in a more harmonious way. This connection between the terms in this class emphasizes the importance of good judgment for the search of social life, using the term "fundamental."

I've heard of quality of life. Quality of life is a person who tends to exercise, seeks to make friends, not to be alone, feeds him/herself well. Good food; do not overdrink. The person having some time for resting. (F1, 62 years)

This proactive movement is focused on elements that constitute a representation of quality of life, based on the gregarious social question, good nutrition, rest, and physical activities. The latter integrate the immediate context of the participants, because the research was performed in an environment that is part of the daily life of the elderly.

The word "food" and its complementary forms were among the main categories mentioned by the participants in the research, with the occurrence of the typologies of food and forms of food related to socialization ("eating out"), and to the economic and financial condition for acquiring what they consider "good food." The elderly emphasized the importance of food quality and healthy eating habits for maintaining health and achieving a satisfactory quality of life.

According to the ascending analysis, the word "food" frequently appears related to the term "eating," and both relate to the word "power." They establish relationships with the terms "good" and "health" that allow us to infer that attitudes toward food and eating are valued as necessary for good health. The terms "good" and "health" are also related to the words "I should" and "physical activity," but not directly to "food." In this sense, physical activity is also interpreted as an attitude that contributes to health.
And living well, having good quality of life, it is having your activities, good food, being with the mind active. It is to try to eat properly, healthy, fat-free food. Always seeking to do an activity, never stand still. (F4, 60 years)

I don't know, I imagine it's when a person lives like, for example, having everything he wants, having the most basic things. It would be something when you want to eat, and you have money to buy clothes that you thought were pretty. (F2, 62 years)

The importance of being in harmony with their families, children, and grandchildren is evident in the uces. They also emphasize the relevance of living with friends, and the fact that they are inserted in, and feel belonging, to a social group.

It's absurd. This way we cannot have a good life. Quality of life has to do with having health as well. Without health, the person is always sad. To live well at home in harmony. Our home first, our children, our family, our friendships. To be prepared for old age. (F17, 61 years)

I think that a person who has quality of life can do what he/ she wants, walk, travel, eat well. Find friends at any time of the day without even worrying about how you will pay the bill. (F8, 60 years)

The social, political, and economic dimensions in the uces were also striking when the participants were questioned about quality of life. In this sense, ideas and meanings related to money, purchasing power, food, product acquisition, housing, and leisure emerged as factors dependent on economic power.

According to the ascending lexical analysis, the terms "money" and "I want" are related to the terms "I had" and "conditions," and both relate to the terms "consider" and "happy." These relationships demonstrate that money is seen as something that enables better conditions (housing, leisure, purchasing power, food), which are important for living well. 
Because dietary products are much more expensive, whole grains are also good for health, everything is very expensive. Then I would buy a lot of fruit so I could eat whole food. But then I was out of money; we buy what is possible. (F23, 66 years)

You can't live without the money because you don't survive if you are hungry. You need to pay the electric power and the water and without the money you can't afford it. (F2, 62 years)

The issue of purchasing power appears in the lexicon composing the uces through explanations of the ability of the elderly to acquire goods, products, and services. This constitutive financial element representative of quality of life is also evident in the conditions of access of these individuals to physical activities conducted by professionals, which represent costs. In the ascending lexical analysis, it is observed that the words "I should" and "physical activity" are related to the terms "money" and "I want," which shows the relation established by the elderly between economic power and the practice of physical activities.

Because I would not be able to find another place. Perhaps, of course, I would have to pay; I would have to have money. And I don't have it. In a way, this helps me a lot. I like it. The teacher is cheerful, playful, says something to try to boost our self-esteem. (F20, 61 years)

The service offered, and the environment of Academia Carioca integrates the representations of quality of life, serving as a means to fulfill the daily life of those who experience the transition from active/productive life as workers to retirement.

The environment influences a lot; here we live well with other people, keep good sense. We can't stay still; you feel depressed if you stop. It's important to be on the move. If you have always moved, worked, when you retire you have to get something to do. You can't stop; you get sick. (M18, 68 years)

And as I'm retired, I have to have the peace of mind that a retiree deserves, in a place where I can safely do my things, being healthy and able to have my leisure at ease. (M12, 70 years)

In the construction of the image of the object quality of life, the elements that constitute the discourse of the reified universe of thought are conveyed by health professionals and the media. In this respect, they present a reified speech of accountability of the other represented by the expression "helps us to do."

We should enjoy life. They are intertwined. The lectures here are a way for us to learn. Many people are diabetic and do not know what diabetes is. Understanding what disease means helps you do the right things. (F10, 66 years)

I hear on television, in that TV program called "Bem Estar"; I really enjoy watching it. Here we also listen to it, in the gym. There are also books that talk about quality of life. They say that we have to maintain a healthy life, eat varied dishes, practice physical activities and not stop the mind. ( $F 4,60$ years)
These uces represent a dimension based on the social image of active aging influenced by health professionals and the media. It is noted that participation in Academia Carioca favors reflection on the benefits of positive attitudes towards health, and regarding the importance of participating in social groups so that the individuals can live longer and with more quality.

Many things are within the program of quality of life, important things, mainly for us, who are older. It is important that we have positive influences, and that's why quality of life is good. They say that the person has an even longer life, because with quality of life the person lives longer and well. (M18, 68 years)

It helps in the way of thinking, living, moving, making friends. All this changes our lives and makes people have quality of life, be happy, not be sad. (F6, 82 years)

\section{DISCUSSION}

The concept of quality of life can be considered multidimensional according to a general or holistic approach. Studies deal with the conceptual aspects and participants' difficulties in discussing their approach ${ }^{(2-3)}$. Considering this multidimensionality, it is well known that the social determinants of health influence people's quality of life, especially the elderly's.

The reference to the health social determinants by the participants in the uces demonstrates the anchoring process of social representation, so that the dimensions that permeate the representational field of these elderly people about quality of life affect them and are meaningful when they relate them to social determinants. Anchoring is the process of cognitive integration that assigns meaning to the object. The subject turns to what is familiar to him, setting the new idea within a preexisting thought ${ }^{(8)}$.

It is observed in the uces that the knowledge and ideas used to construct common sense about food and eating practices have aspects originating from the reified universe of knowledge. Thus, the participants incorporated information discussed in their group, and transformed this knowledge into meaningful knowledge for their daily life, thus justifying good eating practices in benefit of their quality of life.

Knowledge about appropriate food practices and healthy foods is adjusted to a biomedical, therapeutic, prescriptive, and identity discourse, typical of the reified universe. At certain moments, this speech co-occurs with the recognition of the benefits of physical exercise for the participants' quality of life.

The verbs "look for" and "seek" and their variations, "I look for", "searching for," and "I search" reflect actions that the participants accomplish or idealize to be appropriate for attaining quality of life. The noun "person" had an impact on the set of Class 1 lexicons, relating to the verbs cited. These associations reveal a proactive attitude towards quality of life, evidencing an initiative to practice physical activities and satisfaction in participating in social groups.

The presence of these verbs reflects the symbolic dimension of representation, because it has to do with the dissemination of knowledge by the reified universe on the themes 
of physical activity and food, articulated to the promotion of quality of life, through discussions with the health professionals of Academia Carioca and information transmitted in the media, for example, on TV shows. These discussions disseminate a discourse of the accountability of the other, which generates a coherence between the thought of the elderly when they investigate and their action. In this sense, the verbs they use indicate that they take responsibility for the action, incorporating it into their daily lives, and understanding how beneficial it is to their health.

The predominance of terms such as "doing exercises", "not standing still," and "doing activities" also demonstrates this awareness of the importance of practicing physical activities, and the denial of sedentary attitudes. The subjects construct ideas about the object and act according to the influences of the environment to which they belong which, in the case of this research, is evidenced by attitudes that reveal the importance of an active and healthy aging for a successful aging.

The social representation allows us to evaluate how the social life intervenes in the construction of the subject, and how this subject affects the environment in which he lives. The incorporation into everyday life of knowledge provided by the social environment only occurs if it has meaning or affects the person in any way. In this sense, knowledge about the importance of physical activities and good food, disseminated in media such as television programs and during the activities at Academia Carioca contains messages that inspire the elderly, making them incorporate them into their daily lives. This demonstrates the importance of the affective dimension to the representational field.

These data are congruent with other studies that indicate the practice of physical activities as an element that favors the psychophysical health and quality of life of individuals in the aging process ${ }^{(9)}$. A cross-sectional study carried out in Finland, Poland, and Spain evaluated the determinants of the quality of life of elderly people, and showed that the practice of physical activity and the establishment of bonds through the insertion of elderly people into social groups are some of the factors that contribute to the increase in quality of life of the aging population $^{(10)}$. A study carried out in Brazil showed that the elderly did not isolate themselves at home; they sought active insertion into groups in the community, establishing new bonds and friendships ${ }^{(11)}$.

The search for social interaction was also perceived by the participants as a relevant point for quality of life; thus loneliness is translated as negative for well-being. Among the motivations for participation in social groups are the search for improvement in health and quality of life as well as an escape from loneliness, aspects that evidence the important role of social insertion of the elderly for psychic health ${ }^{(12)}$.

The importance of support from family and social relationships for a healthy aging is also highlighted ${ }^{(13)}$. A study conducted in Turkey shows that high levels of social support and the practice of activities of daily living contribute to a better quality of life and lower rates of depression ${ }^{(14)}$. These results reiterate how independence and social participation positively affect the quality of life of the elderly.
On the other hand, fragile health and the incapacities imposed by aging tend to weaken the social interaction and community participation of the elderly, with risks of social isolation and limitations in lifestyle. Therefore, the insertion of these individuals into the free social groups offered by SUS brings benefits to the interaction, as well as favoring changes in lifestyle and maintenance of successful aging ${ }^{(15)}$.

The strong influence of the current economic conditions experienced by the Brazilian population is also observed in the uces. With the economic and financial crisis, metaphors and words that express dissatisfaction and emotional, social, and economic instability have become evident. As we age, the issue of social security becomes present in both the social and economic spheres. With the increase in longevity and better health conditions, the number of elderly people who will benefit from social security increases, which demands greater government spending.

Studies on the financial condition of the elderly also relate purchasing power to quality of life, as it affects access to goods and services, for example, quality food and leisure ${ }^{(16-17)}$. In the results of this research, Class 1 lexicons and their uces show that money allows quality eating and practice of leisure activities that, in their turn, relate to aspects of social satisfaction. This affects attitudes regarding the compliance with advice from health professionals to purchase and consume foods that require better economic conditions.

The need for money for the practice of physical activities as highlighted by the elderly has links with the overvaluation in the media and in society of the cult of the body. Awareness of the benefits of exercise has permeated the people's initiative and increased the search for gyms, which influences the demand of the market. In a study that discussed aspects of the deconstruction of the image of the elderly due to media influence, the dissemination of information that increasingly encourages the adoption of new habits of life and maintenance of a healthy body among the elderly was observed ${ }^{(18)}$.

The imagistic dimension of active aging is disseminated by the media and also by health professionals. The social image of active aging is brought by the media as synonymous with longevity and health and reaches the individual image, which contributes to the search for the Academia.

The recognition of the relevance of the Academia Carioca by the research participants goes beyond the scope of physical health, and reaches the psychological sphere, due to the benefits to mental health. The results show the building of bonds in the context of the group, and the importance of being inserted into a space that intensifies social life and contact with other people that can help the participants to reach psychic wellbeing and quality of life. In a study carried out in a co-living group in the city of Mogeiro in the state of Paraíba, the biopsychosocial contribution of the living spaces was reaffirmed, because after the insertion in the group, the individuals began to show more living satisfaction, and felt more socially valued. The group facilitates conviviality and social relations, as well as facilitating the expression of feelings $s^{(19)}$.

The actions carried out in the environment of the socialization group of the Program Academia Carioca de Saúde go 
beyond the sphere of the practice of physical activities, becoming a mechanism of health promotion through necessary and important information for the subjects inserted into it. Thus, the reified universe of knowledge is present in the representations of participants when using technical knowledge about health care. This occurs through testimonies about healthy practices and the necessary care that they carry out with the purpose of preventing or mitigating the consequences of problems related to non-communicable chronic diseases. These are apprehended in the context of the actions carried out in the group.

The diffusion of strategies and practices that stimulate healthy habits is an alternative allowing for an old age with fewer chronic diseases or functional impairments. However, the economic and social conditions of an individual also directly interfere with the quality of their food and the possibility of carrying out activities, factors that may make the promotion of healthy living habits an even more challenging task for health professionals.

It should be noted that Academia Carioca was planned and structured to be a space for sharing knowledge and information about health care, a place of production of meanings and transformation of attitudes. The elderly who participate in it are aware of the importance of being inserted into groups in which they can socialize and carry out activities to benefit their quality of life. In a study that evaluated aspects of the health-related quality of life of the elderly in situations of social vulnerability, social adversity, lifestyle, health conditions, and functional aspects of social relations stood out as important markers for understanding this phenomenon ${ }^{(20)}$.

\section{Limitations of the study}

Conducting this study in only one field, without possibilities to significantly increase the number of participants, did not allow an analysis by gender and by age group segments.

\section{Contributions for nursing and public policy}

Getting to know the knowledge and practices of the elderly in terms of quality of life allows nursing professionals to plan and implement health-promotion care that is more consistent with the context of the elderly, considering their lives and experiences. In addition, it reaffirms the importance and contribution of Academias de Saúde that are part of the Family Health Clinics, because they are spaces where gerontological nursing has a great opportunity to work, especially the Academia Carioca Program, for the development of better health conditions of the elderly, extending the conditions of multidisciplinary work in health care.

\section{FINAL CONSIDERATIONS}

The social representations of the elderly with regard to quality of life are built on the social determinants of health and on the discourse of social health production, which demonstrates a global understanding of the concept of quality of life. Such representations denote the articulation of knowledge and care practices, with valuation of physical activities and proactive attitudes towards aging. They also provide care for the prevention or mitigation of chronic noncommunicable diseases.

The elderly have communicated their knowledge about what, in the light of their representations, they consider quality of life, and they are able to recognize it in everyday situations, through examples. However, images are identified in their speeches that describe actions and conditions that refer to an understanding of the ideal or imagined quality of life in a discourse about the future, but not the one currently lived by them.

The characterization of practices promoting quality of life evidenced attitudes related to healthy eating habits, daily physical activities, social participation, life and interaction with friends in social groups, the accomplishment of daily tasks with independence and autonomy, support and family contact, the importance of sleep and rest, as well as leisure activities in the company of friends and relatives. These were the main actions of the elderly in favor of their quality of life.

In view of the above, Academia Carioca is part of the daily life of the elderly, promotes their resocialization through dialogue, and allows the construction of knowledge and actions to incorporate healthy attitudes in their daily lives. It is, therefore, a pulsating space of circulation of knowledge on issues that matter to health, which contributes to social insertion and care for the elderly.

\section{REFERENCES}

1. Oliveira AD, Ramos AO, Panhoca I, Alves VLS. A intersetorialidade nas políticas públicas para o envelhecimento no Brasil. Rev Kairós Gerontol [Internet]. 2014 [cited 2017 Jan 10];17(2):91-103. Available from: http://revistas.pucsp.br/index.php/kairos/ article/view/21278/15556

2. Schmidt MI, Duncan BB, Azevedo e Silva G, Menezes AN, Monteiro CA, Barreto SM et al. Chronic non communicable diseases in Brazil: burden and current challenges. Lancet [Internet]. 2011 [cited 2017 Jan 10];377(9781):1949-61. Available from: http:// www.thelancet.com/journals/lancet/article/PIIS0140-6736(11)60135-9/abstract

3. Seidl EMF, Zannon CMLC. Qualidade de vida e saúde: aspectos conceituais e metodológicos. Cad. Saúde Pública [Internet]. 2004 [cited 2017 Feb 08];20(2):580-88. Available from: http://www.scielo.br/pdf/csp/v20n2/27.pdf

4. Pereira EF, Teixeira CS, Santos A. Qualidade de vida: abordagens, conceitos e avaliação. Rev Bras Educ Fís Esporte [Internet]. 2012 [cited 2017 Jan 08]; 26(2):241-250. Available from: http://www.scielo.br/pdf/rbefe/v26n2/07.pdf

5. Moscovici S. A psicanálise, sua imagem e seu público. Petrópolis (RJ): Vozes, 2012.

6. Fontanella BJB, Ricas J, Turato ER. [Saturation sampling in qualitative health research: theoretical contributions]. Cad Saúde Pública [Internet]. 2008 [cited 2017 Feb 01];24(1):17-27. Available from: http://www.scielo.br/pdf/csp/v24n1/02.pdf Portuguese 
7. Apostolidis T. Representations sociales et triangulation: une application en psychologie sociale de la sante. Psic: Teor Pesq [Internet]. 2006 [cited 2016 Dec 05];22(2):211-26. Available from http://www.scielo.br/pdf/ptp/v22n2/a11v22n2.pdf

8. Morera JAC, Padilha MI, Silva DGV, Sapag J. Theoretical and methodological aspects of social representations. Texto Contexto Enferm [Internet]. 2015 [cited 2017 Feb 08];24(4):1157-65. Available from: http://www.scielo.br/pdf/tce/v24n4/0104-0707-tce-24-04-01157.pdf

9. Battaglia G, Bellafiore M, Alesi M, Paoli A, Bianco A, Palma A. Effects of an adapted physical activity program on psychophysical health in elderly women. Clin Interv Aging [Internet]. 2016 Jul [cited 2016 Dec 05];11:1009-15. Available from: https://www.ncbi. nlm.nih.gov/pmc/articles/PMC4973724/.

10. Raggi A, Corso B, Minicuci N, Quintas R, Sattin D, Torres L, Chatterji S, Frisoni BG, Haro JM, Koskinen S, Martinuzzi A, Miret M, Tobiasz-Adamczyk B, Leonardi M. Determinants of quality of life in ageing populations: results from a cross-sectional study in Finland, Poland and Spain. PLoS One [Internet]. 2016 [cited 2017 Jan 10];11(7):e0159293. Available from: https://www.ncbi. nlm.nih.gov/pmc/articles/PMC4951007/.

11. Mantovani EP, Lucca SR, Neri AL. Associations between meanings of old age and subjective well-being indicated by satisfaction among the elderly. Rev Bras Geriatr Gerontol [Internet]. 2016 [cited 2017 Feb 08];19(2):203-22. Available from: http://www. scielo.br/pdf/rbgg/v19n2/en_1809-9823-rbgg-19-02-00203.pdf

12. Bittar C, Lima LCV. O impacto das atividades em grupo como estratégia de promoção da saúde na senescência. Rev Kairós Gerontol [Internet] 2011 [cited 2017 Jan 10];14(4):101-18. Available from: http://revistas.pucsp.br/index.php/kairos/article/ view/10053/7482

13. Araújo LF, Amaral EB, Sá ECN, Coutinho MP. Representações sociais do envelhecimento saudável por homens idosos. Rev Kairós Gerontol [Internet] 2011 [cited 2017 Jan 10];14(6):135-51. Available from http://revistas.pucsp.br/index.php/kairos/article/ view/11704/8427

14. Unsar S, Dindar I, Kurt S. Activities of daily living, quality of life, social support and depression levels of elderly individuals in Turkish society. J Pak Med Assoc [Internet]. 2015 [cited 2017 Jan 10];65(6):642-6. Available from: http://jpma.org.pk/full_article_text.php?article_id = 7380

15. Geib LTC. [Social determinants of health in the elderly]. Ciênc Saúde Coletiva [Internet]. 2012 [cited 2017 Nov 08];17(1):123-33. Available from: http://www.scielo.br/pdf/csc/v17n1/a15v17n1.pdf Portuguese.

16. Irigaray TQ, Trentini CM. Quality of life in elderly women: the importance of the subjective dimension. Estud Psicol [Internet]. 2009 [cited 2017 Jan 10];26(3):297-304. Available from http://www.scielo.br/pdf/estpsi/v26n3/v26n3a03.pdf Portuguese.

17. Tahan J, Carvalho ACD. Reflexões de idosos participantes de grupos de promoção de saúde acerca do envelhecimento e da qualidade de vida. Saude Soc [Internet]. 2010 [cited 2017 Feb 08];19(4):878-88. Available from: http://www.scielo.br/pdf/sausoc/ v19n4/14.pdf

18. Ferreira MG, Bianchi M, Menegócio AM, Zago GM. Desconstruindo a imagem do idoso nos meios midiáticos. Rev Kairós Gerontol [Internet] 2014 [cited 2017 Jan 10];17(4):211-23. Available from: http://revistas.pucsp.br/index.php/kairos/article/ view/23868/17127

19. Cavalcante ERMF, Dantas DS, Araújo DN, Magalhães PAF, Neves MTS. Contribuições de um grupo da terceira idade para a saúde das idosas participantes. Rev Brasci Saúde [Internet] 2015 [cited Jan 10];19(1):11-8. Available from: http://periodicos.ufpb.br/ index.php/rbcs/article/view/15278/15038

20. Camelo LV, Giatti L, Barreto SM. Health related quality of life among elderly living in region of high vulnerability for health in Belo Horizonte, Minas Gerais, Brazil. Rev Bras Epidemiol [Internet]. 2016 [cited 2017 Feb 08];19(2):280-93. Available from: http:// www.scielo.br/pdf/rbepid/v19n2/en_1980-5497-rbepid-19-02-00280.pdf 